\title{
Covid-19'da Cinsiyet Hormonlarının İmmün Yanıt Üzerine Etkileri
}

\author{
Ayşegül YILMAZ1, Demet KAÇAROĞLU² ${ }^{2}$, Yasemin ATICI ${ }^{3}$, \\ Hilal ŞAMANDAR AYDAŞ ${ }^{4}$
}

1 Lokman Hekim Üniversitesi Tıp Fakültesi, Tıbbi Mikrobiyoloji Ana Bilim Dalı, Ankara.

2 Lokman Hekim Üniversitesi Tıp Fakültesi, Tıbbi Biyoloji Ana Bilim Dalı, Ankara.

3 Lokman Hekim Üniversitesi Tıp Fakültesi, Tıbbi Biyokimya Ana Bilim Dalı, Ankara.

4 Lokman Hekim Üniversitesi Tıp Fakültesi, Fizyoloji Ana Bilim Dalı, Ankara.

\section{ÖZET}

Koronavirüs hastalığı 2019 (COVID-19), şiddetli akut solunum sendromu koronavirüs 2'nin (SARS-CoV-2) neden olduğu özellikle akciğerde şiddetli doku hasarına neden olan, yoğun inflamatuvar yanıt oluşturan bulaşıcı bir hastalıktır. Yapılan çalışmalar, COVID-19 enfeksiyonu olan erkeklerin kadınlara göre daha şiddetli semptomlar gösterdiği, yaşlı popülasyonunda COVID-19'dan ölüm riskinin gençlere göre daha yüksek olduğu bildirilmiştir. Erkeklerde COVID-19'un kadınlara göre daha ciddi seyretmesi, cinsiyet hormonlarının bu duruma etkisinin olabileceğini düşündürmektedir. Kadın ve erkeklerde cinsiyet hormon seviyelerindeki farklılık immün yanıtları önemli derecede etkilemektedir. COVID-19 pandemisinin sağlık sistemleri ve küresel ekonomi üzerindeki etkileri göz önüne alındığında, yenilikçi tedavi stratejilerine ihtiyaç duyulmaktadır. Bu doğrultuda, cinsiyet hormon terapileri COVID-19 hastaları için umut verici terapötik stratejiler sağlayabilir. Bu derlemede, COVID-19 enfeksiyonu prognozunda etkili olabilecek cinsiyet hormonlarının immün sistemdeki etkileri ve tedavi stratejileri üzerine yapılan çalışmalar incelenmiştir. Cinsiyet hormonlarının immün sistem üzerindeki etkileri dikkate alınarak uygulanan hormon tedavilerinin klinisyenlere yol göstereceğini ve COVID-19 tedavi protokollerine katkı sağlayacağını düşünmekteyiz.

Anahtar Kelime: COVID-19. SARS-CoV-2. Cinsiyet hormonları. İmmün yanıt. Hormon tedavisi.

Effects of Sex Hormones on Immune Response in Covid-19

\begin{abstract}
Coronavirus disease 2019 (COVID-19) is an infectious disease caused by severe acute respiratory syndrome coronavirus 2 (SARS-CoV-2) that produces an intense inflammatory response, causing severe tissue damage, especially in the lung. Studies have reported that men with COVID-19 infection show more severe symptoms than women, and the risk of death from COVID-19 in the elderly population is higher than young people. The fact that COVID- 19 is more serious in men than in women suggests that sex hormones may have an effect on this situation. Differences in sex hormone levels in men and women significantly affect immune responses. Considering the effects of the COVID-19 pandemics on health systems and the global economy, innovative treatment strategies are needed. Accordingly, sex hormone therapies may provide promising therapeutic strategies for COVID-19 patients. In this review, studies on the effects of sex hormones on the immune system and treatment strategies that may be effective in the prognosis of COVID-19 infection were examined. Considering the effects of sex hormones on the immune system, we think that application of hormone treatment may be a guide for clinicians and contribute to COVID-19 treatment protocols.
\end{abstract}

Key Words: COVID-19. SARS-CoV-2. Sex hormones. Immune response. Hormone therapy.

Geliş Tarihi: 01.Ekim.2021

Kabul Tarihi: 07.Aralık.2021

\section{Ayșegül YILMAZ}

Lokman Hekim Üniversitesi Tıp Fakültesi,

Tıbbi Mikrobiyoloji Ana Bilim Dalı,

Ankara.

Tel: 05356603111

E-posta: aysegul.yilmaz@lokmanhekim.edu.tr

Yazarların ORCID Bilgileri:

Ayşegül YILMAZ: 0000-0002-9541-9853

Demet KAÇAROĞLU: 0000-0003-4920-0516

Yasemin ATICl: 0000-0003-1833-7595

Hilal ŞAMANDAR AYDAŞ: 0000-0001-7651-3732
Koronavirüs hastalığ 2019 (COVID-19), şiddetli akut solunum sendromu koronavirüs 2'nin (SARS-CoV-2) neden olduğu yüksek oranda bulaşıcı bir hastalıktır ${ }^{1,2}$. COVID-19, ilk olarak Çin'in Wuhan şehrinde 2019 yılının Aralık ayında ortaya çıkmış olup, Mart 2020'de Dünya Sağlık Örgütü (WHO) tarafından küresel pandemi olarak duyurulmuştur ${ }^{3}$.

Johns Hopkins Üniversitesi'nin güncellenmiş epidemiyolojik verileri, Eylül 2021'nin sonlarına doğru COVID-19 nedeniyle 231 milyonun üzerinde vaka ve 4 milyonun üzerinde ölüm olduğunu göstermektedir ${ }^{4}$. SARS-CoV-2 dünya çapında hızla yayılmaya devam etmektedir. Yapılan çalışmalarda, COVID-19 enfeksi- 


\section{A. Yılmaz, ark.}

yonu olan erkeklerin kadınlara göre daha şiddetli semptomlar gösterdiği, yaşlı popülasyonunda COVID19'dan ölüm riskinin gençlere göre daha yüksek olduğu bildirilmiştir. Hem erkek hem de kadın hastalarda genç yaş, COVID-19'dan korunmada avantaj sağlamaktadir $^{4-11}$.

SARS-CoV-2, anjiyotensin dönüştürücü enzim tip 2 (ACE-2) reseptörü ve transmembran serin proteaz 2 (TMPRSS2) reseptörü yoluyla hücreye girer ${ }^{12}$. Cinsiyet hormonları ACE-2 ve TMPRSS2 reseptörlerinin ekspresyonunu değiştirdiği için viral yükü etkiler.

Bağışıklık yanıtındaki cinsiyet farklılıkları, hormonların doğrudan etkisinden veya kromozomal farklılıklardan kaynaklanabilir ${ }^{13}$. Cinsiyet hormonları, sadece SARS-CoV-2'nin hücre içine girișini ve yükünü etkilemekle kalmaz, aynı zamanda klinik belirtileri, komplikasyonları ve hastalığın prognozunu da şekillendirebilir. Cinsiyet hormonlarının seviyeleri, hem doğal hem de adaptif bağışıklık yanıtının düzenlemesinde rol oynar ${ }^{14}$. Ayrica yaşa bağlı olarak azalan cinsiyet hormon seviyeleri, yaşlı bireylerde proinflamatuar yanıtın artmasina ve COVID-19 enfeksiyonunun şiddetlenmesine neden olabilir ${ }^{15}$

Birçok bulaşıcı hastalıkta kadınların erkeklerden daha güçlü bir bağışıklık yanıtı oluşturduğu gözlemlenmiştir. Genel olarak, kadın bağışıklık sistemi patojenlere daha güçlü tepki vererek daha yüksek miktarlarda interferon ve antikor üretir; esas olarak bu koruyucu etkiyi östrojenin sağladığı bilinmektedir ${ }^{16}$. Testosteronun bağışıklık yanıtları üzerindeki etkileri, östrojenler kadar belirgin değildir ve bu durum $\mathrm{X}$ kromozomu kaynaklı olabilir ${ }^{17}$.

COVID-19 enfeksiyonu için tedavi stratejilerinde, vaka ve ölüm oranlarının altında yatan sebeplerde cinsiyet hormonlarının etkisinin anlaşılması, klinik ve halk sağlığı açısından geniş bir öneme sahiptir. Cinsiyet hormonlarındaki farklılıklar, COVID-19 enfeksiyonunun başlangıcına, ilerlemesine hatta aşı etkinliğine ve ilaç yanıtına katkıda bulunabilir. Bu derlemede, COVID-19 enfeksiyonunda cinsiyet hormonlarının immün sistem üzerindeki etkileri detaylı olarak incelenerek bu hormonlar hedefli terapötik yaklaşımlar tartışılmıştır.

\section{Östrojenler ve Progesteron}

Östrojenler, genel olarak ovaryumlar tarafindan sentezlenir. Aynı zamanda, erkeklerde az miktarda testislerde ve her iki cinsiyette adrenal bezlerde, beyinde ve yağ dokusunda da üretilebilir. Östrojenler; estron, estradiol (E2), estriol ve estetrol olmak üzere 4 major gruptan oluşmaktadır ${ }^{18}$. Bunlardan (E2), üreme çağındaki memeli dişilerin serumunda bulunan ana östrojendir $^{19}$. Östrojenler, aromataz enziminin androjenlerin demetilasyonunu katalizlemesiyle oluşturulur ${ }^{20}$. Östrojenlerin genital sistem, kas-iskelet sistemi, kar- diyovasküler sistem, sinir sistemi üzerine etkileri yaygın olarak bilinirken son y1llarda immün sistem üzerinde de önemli etkileri olduğu gösterilmiştir ${ }^{14,21}$. Östrojenler, immün sistem hücrelerinde etkilerini reseptörlerle etkileşim yoluyla hücrelerin antijen sunumunu, olgunlaşmasını, farklılaşmasını, çoğalmasını ve sitokin üretimini düzenleyerek gösterir ${ }^{22}$. Östrojenler, immün hücrelerdeki fonksiyonlarını spesifik reseptörlerine bağlanarak sinyal yolakları üzerinden protein sentezi regülasyonuyla gösterir ${ }^{23}$.

$\mathrm{T}$ ve $\mathrm{B}$ lenfosit, timosit, $\mathrm{T}$ regülatör hücre (Treg), monosit, makrofaj, dendritik hücrenin alt tipleri, doğal öldürücü hücreler (NK) gibi immün sistem hücreleri östrojen reseptör alfa (Er $\alpha$ ), östrojen reseptör beta $(\operatorname{Er} \beta)$ ve $G$ protein ilişkili östrojen reseptör (GPER) gibi östrojen reseptörlerini farklı düzeylerde eksprese ederler $^{24,25}$. Östrojenlerin en çok üretilen ve reseptör afinitesi en yüksek formu olan E2'nin, antiinflamatuvar ve immün sistemi güçlendirici etkileri $\operatorname{vardır}^{26}$. E2 seviyesi kadınlarda daha yüksek olduğu için koronavirüs gibi viral enfeksiyonlarda ve aşılamada erkeklerden daha güçlü immün yanıt oluşmasına neden olur ${ }^{27}$. E2 yüksek konsantrasyonlarda; IL-6, IL$1 \beta$, TNF-alfa gibi COVID-19 sitokin firtınasında önemli olan proinflamatuvar sitokinlerin üretimini bask1lar ve makrofaj proliferasyonunu azaltır ${ }^{28}$. E2, lökositlerde kemokin ligandı 2 (CCL2) ekspresyonunu doğrudan baskılayarak nötrofillerin ve monositlerin akciğerlerdeki inflamasyon bölgesine migrasyonunu engeller $^{29}$. Yüksek doz ve uzun süre E2 maruziyetinin NK'larda sitotoksik aktiviteyi azalttı̆̆ 1 gösterilmiştir ${ }^{30}$. Östrojen, plazmasitoid dendritik hücrelerde Toll Benzeri Reseptör (TLR) üzerinden IRF-3 sinyal molekülü aracılığıyla Tip1 interferonların sentezlenmesini uya$\mathrm{rir}^{31}$. Tip1 interferonların eksikliğinde ise COVID19'un daha şiddetli seyir gösterdiği belirtilmiştir ${ }^{32}$.

E2 düzeyi yüksek konsantrasyonlarda iken, antijen sunan hücrelerin (ASH) sayı ve fonksiyonunu iyileştirdiğini gösteren çalışmaların yanı sıra dendritik hücrelerin işlevini azalttığını gösteren çalışmalar da bulunmaktadır $^{19}$. Fakat artmış ASH'ler viral protein yerine vücudun kendi antijenlerini sunmaya başlar. Bu durum Th2 yanıtını arttırarak otoantikor üretimine neden olduğu için COVID-19 sonrası kadınlarda otoimmüniteyi tetikler ${ }^{33}$. E2, CD4+ Th proliferasyonunu uyararak antiinflamatuar sitokinlerin salgılanmasına neden olur.E2 yüksek konsantrasyonlarda Th2 yanıtını uyarır ve IL-4 salınımını arttırır ${ }^{28}$. COVID-19'da sitokin firtınasına neden olan makrofaj aktivasyon sendromununun oluşmaması için doğru noktada Th1 yanıtından Th2 yanıtına geçişin olması gerekmektedir ve bu süreçte dengeli aktivasyon çok önemlidir ${ }^{34}$. COVID-19'da erkeklerde ve postmenopozal kadınlarda ölüm oranının artmasının nedenlerinden biri, düşük östrojenden dolayı Th1/Th2 dengesinin bozulmas1 sayılabilir $^{35}$. Ayrıca postmenopozal kadınlarda östrojenin seviyelerinin azalmasına bağlı olarak kardiyo- 


\section{Covid-19'da Cinsiyet Hormonları ve İmmün Yanıt}

vasküler hastalıkların insidansı da $\operatorname{artmaktadır}^{36}$. Bu kardiyovasküler komplikasyonlar, postmenopozal kadınlarda COVID-19 enfeksiyonun daha şiddetli seyretmesine neden olarak klinik tabloyu daha da kötüleştirmektedir ${ }^{37}$. E2'nin B hücresinin aktivasyonunu ve proliferasyonunu uyararak antikor üretimini arttırdığ1 gösterilmiştir ${ }^{28}$. Yüksek östrojen Th2 yanıtını arttırarak B hücre aktivasyonuna neden olduğu için COVID-19 geçiren üreme çağındaki kadınlarda daha yüksek antikor üretimi gerçekleşirir ${ }^{38}$.

Progesteron her iki cinsiyette de bulunur ve kadinlarda gebelik sırasında plasenta tarafından yüksek miktarlarda üretilir ${ }^{39}$. Menstrual döngünün luteal fazında ve hamilelikte yüksek seviyelerde bulunan progesteron hormonu genel olarak immün sistemi baskılayıc fonksiyon göstermektedir ${ }^{40}$. Progesteron reseptörleri lenfoid organlarda, doğal ve adaptif bağışıklık hücrelerinde intraselüler veya membrana bağlı olarak bulunabilmektedir. Progesteron, proinflamatuvar sitokinlerin üretimini inhibe ederken antiinflamatuvar sitokinlerin üretimini destekler ${ }^{41}$. Progesteron, immün yanıtı Th1 tipinden Th2 tipine doğru ilerlettiği için için COVID-19'daki sitokin firtınasının önüne geçilmesine yardımcı olur ${ }^{28}$. Progesteronun akciğerlerdeki epidermal büyüme faktörü olan amfiregülinin ekspresyonunu arttırdığ 1 için de doku hasarının engellenmesinde rol oynar ${ }^{42}$. Hamile kadınlarda E2 ve progesteron seviyelerinin yüksek olması SARS-CoV-2 enfeksiyonundan direkt korumasa da ciddi seyretmesini engellediği gösterilmiştir ${ }^{28}$.

\section{Testosteron}

Erkeklerde baskın cinsiyet hormonları olan androjenler, esas olarak gonadlar ve adrenal bezler tarafindan üretilmektedir. Androjenler arasında; testosteron, dihidrotestosteron (DHT), androstenedion, androstenediol ve dehidroepiandrosteron (DHEA) bulunmaktadır ve DHT en güçlü olanıdır ${ }^{43}$. Testosteron ve dihidrotestosteron gibi androjenlerin etkilerine, ligand bağımlı bir nükleer transkripsiyon faktörü ve steroid hormon nükleer reseptör ailesinin bir üyesi olan androjen reseptörleri (AR) aracılık etmektedir ${ }^{44}$. AR'ler; kardiyovasküler, hematopoietik, sinir, üreme ve bağ1ş1klık sistemi dahil olmak üzere birçok sistemde görevli çeşitli hücre ve dokularda eksprese edilmektedir. $\mathrm{Bu}$ şekilde androjenler biyolojik etkilerini göstermektedir ${ }^{44}$.

Genel olarak androjenler, immün hücrelerin çoğunda doğrudan veya dolaylı olarak immün baskılayıcı etkiler göstermektedir. Bununla birlikte, androjenlerin etkileri karmaşık olduğundan baskılayıcı veya aktive edici olarak sınıflandırılması zordur ${ }^{13}$.

Androjenler esas olarak doğal bağışıklıkta hücre migrasyonu ve apoptoz sürecine etki etmektedir ${ }^{45}$. Androjenler nötrofillerin, NK hücrelerin ve makrofaj- ların proinflamatuvar yanıtlarını azaltır ${ }^{46}$. Androjenler, MHC sınıf II ve ko-stimülatör moleküllerin gen ekspresyonunu azaltarak antijen sunumunu inhibe etmektedir. B lenfosit ve Th1 yanıtlarını inhibe ederken Th2, Treg ve Th17 yanıtlarının aktivasyonunu indüklemektedir $^{13,45}$.

Testosteron, genç kadınlarda östrojenin etkisine benzer şekilde, genç erkeklerde koruyucu bir antiinflamatuvar etkiye sahip olabilir. Testosteronun hem hücresel hem de hümoral bağışıklık sistemlerinin baskılanması yoluyla anti-inflamatuvar fonksiyonlara sahip olduğu bildirilmektedir. Testosteronun östrojene benzer şekilde NF-KB proinflamatuar yolunun inhibisyonu yoluyla IL-6 ve TNF-alfa'nın aktivitesini baskıladığ1 gösterilmiştir ${ }^{47}$. Testosteron ayrıca, IL-10 ve transforme edici büyüme faktörü- $\beta$ (TGF- $\beta$ ) ekspresyonunu artırarak AR sinyali yoluyla Smad'lar üzerinden anti-inflamatuvar yanıtı geliștirmektedir ${ }^{39,48}$.

Testosteron eksikliği ise otoimmün hastalık ve Creaktif protein (CRP), TNF ve IL-6 gibi inflamatuvar belirteçlerde artış ile bağlantılıdır ${ }^{49}$. SARS-CoV-2 ile enfekte olmuş hipogonadal erkeklerde artan nötrofil sayısı sitokin firtınası ile ilişkilendirilmektedir ${ }^{50,51} . \mathrm{Bu}$ yüzden, erkeklerde daha düşük testosteron seviyelerinin enfeksiyon şiddetini artırabileceği anlamına gelmektedir $^{31}$. Yaşlanan erkeklerde görülebilen düşük testosteron seviyeleri de IL-6 gibi yüksek inflamatuvar belirteçlerle bağlantılıdır ve pnömoniden sonra artan akciğer hasarı riskinin altında yatan sebep olabilir ${ }^{52}$.

Testosteron ayrıca, SARS-CoV-2'nin viral girişini artıran TMPRSS2'nin çeşitli dokularda ekspresyonunu $\operatorname{artırmaktad}_{10}{ }^{53,54}$. TMPRSS2'nin androjenler tarafindan bu şekilde düzenlenmesi, erkeklerde COVID-19'a karşı artan duyarlılığı açıklayabilir ${ }^{55}$. Ancak, yakın tarihli bir çalışma, akciğer dokusundaki yapısal TMPRSS2 ekspresyonunun erkekler ve kadınlar arasında farklılık göstermediğini ve kadınlarda düşük androjen düzeylerinin akciğerlerde bu TMPRSS2 ekspresyonunu sürdürmek için yeterli olabileceğini göstermiştir ${ }^{55,56}$

SARS-CoV-2, giriş reseptörü olarak ACE-2'yi kullanarak akciğer alveoler epitel hücrelerini enfekte etmektedir. ACE-2 reseptörlerinin az olması, akciğerlerin korunmasinda rol oynar ${ }^{57}$. Bazı yazarlar, erkek hastalarda virüsten kaynaklanan artan morbidite ve mortalitenin, erkeklerde artan ACE2 ekspresyonuna ${ }^{58}$ bağlı olduğunu öne sürerken erkekler ve dişiler arasinda ACE2 ekspresyonunda anlamlı bir fark bulamamış çalışmalar da bulunmaktadır ${ }^{59}$. Klinik öncesi çeşitli çalışmalarda da, erkek ve dişi fare modelleri arasında ACE-2 ifadesinde bir fark olmadığı gösterilmiştir $^{60}$.

Erkeklerde COVID-19 duyarlılığında ACE2'nin aşırı ekspresyonunun rolünü belirlemek için daha fazla çalışmaya ihtiyaç duyulmaktadır ${ }^{55,60}$. 


\section{A. Yılmaz, ark.}

\section{Covid 19 Hastalarında Cinsiyet Hormon Tera- pisi Uygulamaları}

Dünya genelinde COVID-19 nedenli hastaneye yatış, entübasyon ve ölüm oranlarının incelenmesinde hastalık şiddetinin, erkeklerde kadınlara göre 1,5-2 kat daha fazla olduğu görülmüştür. Cinsiyet dikkate alınarak sonuçların değerlendirilmesi, COVID-19 enfeksiyon oranlarının azalmasında faydalı olabilir ${ }^{5}$.

Klinik çalışmalar, inflamasyonun kadınlarda erkeklere kıyasla daha hızlı düzeldiğini göstermektedir ${ }^{61}$. Östrojenin immün yanıt baskılayıcı etkisi olduğu için yaşlı kadınlarda hormon replasman tedavisinin potansiyel bir terapötik rolü olduğu düşünülmektedir ${ }^{62}$. Ekzojen uygulanan östrojen ve testosteron tedavileri, kortikosteroidler gibi COVID-19'da oluşan aşırı inflamatuvar yanıtın neden olduğu doku hasarını hafifletmek için terapötik bir potansiyele sahiptir ${ }^{63}$. Şiddetli seyreden COVID-19'da, östrojenin immün yanıt oluşumundaki dengeyi olumlu yönde etkilediği belirtilmiş, ayrıca trombotik diyatez oluşumunu ve mortaliteyi etkilediğ için östrojen tedavisi önerilmiştir ${ }^{15}$. Bunun yanı sıra östrojen tedavisi spesifik malignitelerde ve özellikle tromboemboli insidansında artışa sebep olabilmektedir. Bu nedenle özellikle postmenopozal dönemde hormon replasmanının dikkatli kullanılması gerektiği belirtilmektedir. Özellikle COVID-19 enfeksiyonunda yüksek doz tedavi uygulanmasının venöz tromboemboli riskinde artışa yol açabileceği de dikkate alınmalıdır ${ }^{64}$. In vivo çalışmalarda burun spreyi olarak kullanılan soya izoflavonları gibi düşük dozlu doğal östrojenlerin, fagositler, dendritik hücreleri ve NK hücrelerinin aktivitesini artırdığı için lokal nazal bağışıklık sistemini aktive ederek virüsün yayılmasını engelleyebileceği gösterilmiştir ${ }^{15}$. Randomize bir klinik çalışmada, SARS-CoV-2'nin bağlandığı reseptörlerin ekspresyonunu etkilediği bilinen estradiol, flavonoid kersetin ve D vitamini ile oluşturulan üçlü kombinasyonun, COVID-19 tedavisinde potansiyel bir terapötik olarak kullanılması önerilmiştir ${ }^{65}$. Ebola enfeksiyonunda uygulandığı gibi, seçici östrojen reseptör modülatörleri ile (SERM), proinflamatuvar ve anti-inflamatuvar sitokin ekspresyonlarının düzenlenmesi, COVID -19 için başka bir potansiyel terapötik hedef olarak belirtilmiştir ${ }^{66}$.

Östrojenin yanı sıra progesteronun yüksek fizyolojik konsantrasyonları; anti-inflamatuvar yanıtları desteklemek ve antikor üretimini uyarmak için kullanılabilir. $\mathrm{Bu}$ bağlamda COVID-19'lu hastalarda, östrojen ve progesteronun kombine tedavisinin, sitokin firtınasını hafifletebileceği belirtilmiştir ${ }^{28}$.

Genel olarak testosteron replasman tedavisinin, IL-1 $\beta$, IL-6 ve TNF-alfanın üretimini azaltmak veya salınımını engellemek için kullanıldığı belirtilmiştir ${ }^{67}$. Proinflamatuvar sitokinler üzerindeki etkisi ve testosteron replasmanı tedavisinin olumlu profili göz önüne alın- dığında, hipogonadizm ve COVID-19 enfeksiyonu olan hastalarda testosteron tedavisinin önemli bir rolü olabileceği belirtilmiştir. Yaygın kullanım için bu konuda daha geniş kapsamlı klinik çalışmalara ihtiyaç

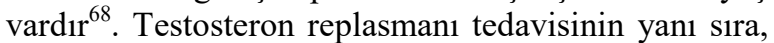
TMPRSS2'nin SARS-CoV-2 invazyonunu kolaylaştırdığı için COVID-19 hastalarında anti-androjen tedavisi gündeme gelmiştir ${ }^{69}$. Bu bağlamda, antiandrojen tedavisi; virüsün akciğere girişini engelleyerek TMPRSS2'yi bloke etmesi ve testosteronun immün baskılayıcı etkilerini azaltarak immün yanitı iyileştirmesi yoluyla faydalı olabilir. Düşük testosteron seviyeleri ile enfeksiyonun erken evrelerinde antiandrojen tedavisi etkili olabilir. Fakat özellikle yaşı erkeklerde görülen hipogonadizm, COVID-19 nedeniyle gelişen alt solunum yolu enfeksiyonlarının kötüleşmesinde risk faktörü oluşturabilir ${ }^{70}$. Yaşl1lık, kötü COVID-19 sonuçları için en önemli risk faktörlerinden biri olduğu için, Haitao ve ark. gelecekteki araştırmalarda, COVID-19 teşhisi konan yaşlı kadın ve erkeklerde hormon replasman tedavisinin rolünün ele alınması gerektiğini vurgulamıştır ${ }^{71}$.

Son zamanlardaki çalışmalarda; SARS-CoV-2'nin dokuya zarar veren bağışıklık yanıtını azaltmak için inflamatuvar sitokin reseptörü blokörleri (IL-1 için) ve monoklonal antikorlar (IL-6 için tocilizumab ve sarilumab) gibi ajanların kullanılması önerilmektedir ${ }^{63}$. Bununla birlikte, bu ajanların, hastaların bağışıklık fonksiyonu üzerinde oluşturabileceği olumsuz etkiler de göz önünde bulundurulmalıdır ${ }^{62}$. Cinsiyet hormonu replasman tedavileri, COVID-19 hastalarında uzun süreli uygulamadan kaynaklı yan etkileri azaltmak için kısa süreli olarak tercih edilmelidir ${ }^{69}$.

\section{Sonuç}

COVID-19 klinik prognozunda immünomodülasyonu etkileyen faktörler giderek önem kazanmaktadır. Kadin ve erkeklerde COVID-19'un farklı seyretmesi, cinsiyet hormonlarının da bu duruma etkisinin olabileceğini düşündürmektedir. Kadın ve erkeklerde yaşla birlikte değișen cinsiyet hormon seviyeleri, immün yanıtları önemli derecede etkilemektedir. Literatürdeki çalışmalar doğrultusunda, hormon tedavisinin tek başına ve/veya antiviral tedavilerle kombine edilerek uygulanması COVID-19 hastaları için etkili terapötik stratejiler sunabilir. Bu stratejiler COVID-19 enfeksiyonunun tedavi sürecinde temel prensip olmamakla birlikte tedavi sürecini hızlandırabilmek için hormonlar, adjuvan ajanlar olarak kullanılabilir. $\mathrm{Bu}$ sayede COVID-19 hastalarının iyileşmesini destekleyerek ve mortalite oranlarını düşürerek hospitalizasyonun azalmasına katkıda bulunabilir. Bu derlemenin, uygun hormon tedavisinin seçiminde klinisyenlere yol göstereceğini ve COVID-19 tedavi protokollerine katk1 sağlayacağını düşünmekteyiz. 


\section{Covid-19'da Cinsiyet Hormonları ve İmmün Yanıt}

Etik Kurul Onay Bilgisi: Çalışma derleme makale olup etik kurul iznine gerek yoktur.

Araştırmacı Katkı Beyanı: Fikir ve tasarım: A.Y.; Veri toplama ve issleme: A.Y., D. K., Y.A., H.S..A; Analiz ve verilerin yorumlanmas1: A.Y., D. K., Y.A., H.Ş.A; Makalenin önemli bölümlerinin yazılması: A.Y., D. K., Y.A.,H.Ş.A.

Destek ve Teşekkür Beyanı: Bu çalışma herhangi bir finansal kuruluş tarafindan desteklenmemiştir.

Çıkar Çatışması Beyanı: Makale yazarlarının çıkar çatıșmas beyanı yoktur.

\section{Kaynaklar}

1. Zhou P, Yang XL, Wang XG et al.A pneumonia outbreak associated with a new coronavirus of probable bat origin. Nature. 2020;579(7798):270-273.

2. Gorbalenya AE, Baker SC, Baric RS et al. The species Severe acute respiratory syndrome-related coronavirus: classifying 2019-nCoV and naming it SARS-CoV-2. Nat Microbiol. 2020;5, 536-544.

3. Wu Z, McGoogan JM. Characteristics of and Important Lessons From the Coronavirus Disease 2019 (COVID-19) Outbreak in China: Summary of a Report of 72314 Cases From the Chinese Center for Disease Control and Prevention. JAMA. 2020;323(13):1239-1242.

4. coronavirus.jhu.edu/map.html [homepage on the Internet] COVID-19 Dashboard by the Center for Systems Science and Engineering (CSSE) at Johns Hopkins University (JHU) [updated 22 September 2021]. www.coronavirus.jhu.edu/map.html

5. Richardson S, Hirsch JS, Narasimhan $M$ et al. Presenting Characteristics, Comorbidities, and Outcomes Among $5700 \mathrm{~Pa}$ tients Hospitalized With COVID-19 in the New York City Area JAMA. 2020;323(20):2052-2059.

6. Livingston E, Bucher K. Coronavirus Disease 2019 (COVID19) in Italy. JAMA. 2020;323(14):1335.

7. Chen N, Zhou M, Dong X et al. Epidemiological and clinica characteristics of 99 cases of 2019 novel coronavirus pneumonia in Wuhan, China: a descriptive study. Lancet. 2020;395(10223):507-513.

8. Li Q, Guan X, Wu P et al. Early Transmission Dynamics in Wuhan, China, of Novel Coronavirus-Infected Pneumonia. N Engl J Med. 2020;382(13):1199-1207.

9. Yang $\mathrm{X}, \mathrm{Yu} \mathrm{Y,Xu} \mathrm{J} \mathrm{et} \mathrm{al.} \mathrm{Clinical} \mathrm{course} \mathrm{and} \mathrm{outcomes} \mathrm{of}$ critically ill patients with SARS-CoV-2 pneumonia in Wuhan, China: a single-centered, retrospective, observational study. Lancet Respir Med. 2020;8(5):475-481.

10. Meng Y, Wu P, Lu W et al. Sex-specific clinical characteristics and prognosis of coronavirus disease-19 infection in Wuhan, China: A retrospective study of 168 severe patients. PLoS Pathog. 2020 Apr 28;16(4):e1008520.

11. Gebhard C, Regitz-Zagrosek V, Neuhauser HK et al.Impact of sex and gender on COVID-19 outcomes in Europe. Biol Sex Differ. 2020;11(1):29.

12. Atıcı Y, Elbaş Y, Bakır F, Yıldırımkaya MM. COVID-19 enfeksiyonunda ACE ve ACE2 reseptörlerinin potansiyel rolü. Yücel D, editör. COVID-19 Pandemisinde Tibbi Biyokimyanın Artan Rolü. 1. Bask1. Ankara: Türkiye Klinikleri; 2021:57-62.

13. Sellau J, Groneberg M, Lotter H. Androgen-dependent immune modulation in parasitic infection. Semin Immunopathol. 2019;41(2):213-224.

14. Taneja V. Sex Hormones Determine Immune Response. Front Immunol. 2018;27(9):1931

15. Pivonello R, Auriemma RS, Pivonello $\mathrm{C}$ et al. Sex Disparities In Covid-19 Severity And Outcome: Are Men Weaker or Women Stronger? Neuroendocrinology. 2020 Nov 26:1-20.
16. Straub R.H. The complex role of estrogens in inflammation. Endocr Rev 2007; 28:521-574.

17. Pontecorvi G, Bellenghi M, Ortona E et al. microRNAs as new possible actors in gender disparities of COVID-19 pandemic. Acta Physiol. 2020;230:e13538.

18. Kumar RS, Goyal N. Estrogens as regulator of hematopoietic stem cell, immune cells and bone biology. Life Sci. 2021;269:119091.

19. Medina-Estrada I, Alva-Murillo N, López-Meza JE et al. Immunomodulatory Effects of $17 \beta$-Estradiol on Epithelial Cells during Bacterial Infections. J Immunol Res. 2018;2018:6098961.

20. Blakemore J, Naftolin F. Aromatase: Contributions to Physiology and Disease in Women and Men. Physiology (Bethesda). 2016;31(4):258-69.

21. Patel S, Homaei A, Raju AB et al. Estrogen: The necessary evil for human health, and ways to tame it. Biomed Pharmacother. 2018;102:403-411.

22. Bhatia A, Sekhon HK, Kaur G. Sex hormones and immune dimorphism. Scientific World Journal. 2014; 1-8.

23. Altunkaynak BZ, Ünal D,Aksak S,Ünal B. Östrojen Hormonu Ve Menopoz. Ondokuz Mayis Universitesi Tip Dergisi. 2012; 29(4):252-256.

24. Koenig A, Buskiewicz I, Huber SA. Age-associated changes in estrogen receptor ratios correlate with increased female susceptibility to coxsackievirus B3-induced myocarditis, Frontiers in Immunology. 2017;16(8):1585.

25. Cady N, Peterson SR, Freedman SN et al. Beyond Metabolism: The Complex Interplay Between Dietary Phytoestrogens, Gut Bacteria, and Cells of Nervous and Immune Systems. Frontiers in Neurology. 2020;11:150.

26. Lee TP, Chiang BL. Sex differences in spontaneous versus induced animal models of autoimmunity. Autoimmun Rev. 2012;11(6-7):A422-9

27. Klein SL, Marriott I, Fish EN. Sex-based differences in immune function and responses to vaccination. Trans R Soc Trop Med Hyg. 2015;109(1):9-15.

28. Mauvais-Jarvis F, Klein SL, Levin ER. Estradiol, Progesterone, Immunomodulation, and COVID-19 Outcomes. Endocrinology. (2020);161(9):1-8.

29. Ghosh S, Klein RS. 'Sex Drives Dimorphic Immune Responses to Viral Infections. The Journal of Immunology. 2017;198(5):1782-1790.

30. González DA, Díaz BB, Rodríguez Pérez Mdel C et al. Sex hormones and autoimmunity. Immunol Lett. 2010;6,133(1):613

31. Raza HA, Sen P, Bhatti OA et al. Sex hormones, autoimmunity and gender disparity in COVID-19. Rheumatol Int. 2021;41(8):1375-1386.

32. Wang Z, Pan H, Jiang B. Type I IFN deficiency: an immunological characteristic of severe COVID-19 patients. Signal Transduct Target Ther. (2020);5(1):198.

33. Liu Y, Sawalha AH, Lu Q. COVID-19 and autoimmune diseases. Current Opinion in Rheumatology. 2021; 33(2):155-162.

34. Brodin P. Immune determinants of COVID-19 disease presentation and severity. Nature Medicine. 2021;27(1): 28-33.

35. Garg R, Agrawal P, Gautam A et al. A. COVID-19 Outcomes in Postmenopausal and Perimenopausal Females: Is Estrogen Hormone Attributing to Gender Differences? J Midlife Health. 2020;11(4):250-256.

36. Pardhe, B. D., Ghimire, S., Shakya, J et. al. Elevated Cardiovascular Risks among Postmenopausal Women: A Community Based Case Control Study from Nepal. Biochemistry Research International. 2017; Article ID 3824903.

37. Bansal M. Cardiovascular disease and COVID-19. Diabetes \& Metabolic Syndrome. 2020;14(3):247-250. 


\section{A. Yılmaz, ark.}

38. Klein SL. Morgan R. The impact of sex and gender on immunotherapy outcomes. Biology of Sex Differences. 2020;11(1):1-13.

39. Kadel S, Kovats S. Sex Hormones Regulate Innate Immune Cells and Promote Sex Differences in Respiratory Virus Infection. Front Immunol. 2018;9:1653.

40. Ghare Naz MS, Banaei M, Dashti S et al. An overview of sex hormones in relation to SARS-CoV-2 infection. Future Virol. 2021; Jul:10.2217/fvl-2021-0058

41. Klein SL, Flanagan KL.Sex differences in immune responses Nature Reviews Immunology. 2016;16(10):626-638.

42. Hall OJ, Limjunyawong N, Vermillion MS et al. ProgesteroneBased Therapy Protects Against Influenza by Promoting Lung Repair and Recovery in Females. PLoS Pathog. 2016;12(9):e1005840.

43. Marchetti PM, Barth JH. Clinical biochemistry of dihydrotestosterone. Ann Clin Biochem. 2013;(50):95-107.

44. Davey RA,Grossmann M. Androgen Receptor Structure, Function and Biology: From Bench to Bedside. The Clinical Biochemist. Reviews. 2016;37(1):3-15.

45. Tzanakakis G, Giatagana EM, Kuskov A et al. Proteoglycans in the Pathogenesis of Hormone-Dependent Cancers: Mediators and Effectors. Cancers (Basel). 2020;12(9):2401.

46. Billi AC, Kahlenberg JM, Gudjonsson JE. Sex bias in autoimmunity. Curr Opin Rheumatol. (2019);31(1):53-61

47. Traish A, Bolanos J, Nair S et al. Do Androgens Modulate the Pathophysiological Pathways of Inflammation? Appraising the Contemporary Evidence. J Clin Med. 2018;7(12):549.

48. Jeremy M. Auerbach MK.Testosterone's Role in COVID-19. The Journal of Sexual Medicine. 2021;18,(5):843-848.

49. Baillargeon J, Al Snih S, Raji MA et al. Hypogonadism and the risk of rheumatic autoimmune disease. Clin Rheumatol 2016;35(12):2983-2987.

50. Rastrelli G, Di Stasi V, Inglese F et al. Low testosterone levels predict clinical adverse outcomes in SARS-CoV-2 pneumonia patients. Andrology. 2021;9(1):88-98.

51. Wang $\mathrm{D}, \mathrm{Hu} \mathrm{B}, \mathrm{Hu} \mathrm{C}$ et al. Clinical Characteristics of 138 Hospitalized Patients With 2019 Novel Coronavirus-Infected Pneumonia in Wuhan, China. JAMA. 2020;323(11):1061-1069.

52. Li H, Manwani B, Leng SX. Frailty, inflammation, and immunity. Aging Dis. 2011;2(6):466-73

53. Pozzilli P, Lenzi A. Commentary: Testosterone, a key hormone in the context of COVID-19 pandemic. Metabolism. 2020; Jul(108): 154252 .

54. Hussain AN, Hussain F, Hashmi SK. Role of testosterone in COVID-19 patients- A double-edged sword? Med Hypotheses. 2020; Nov(144):110287.

55. Mjaess G, Karam A, Aoun F et al. COVID-19 and the male susceptibility: the role of ACE2, TMPRSS2 and the androgen receptor. Prog Urol. 2020;30(10):484-487.

56. Stopsack KH, Mucci LA, Antonarakis ES et al. TMPRSS2 and COVID-19: Serendipity or Opportunity for Intervention? Cancer Discov. 2020;10(6):779-782.
57. Li G, He X, Zhang L et al. Assessing ACE2 expression patterns in lung tissues in the pathogenesis of COVID-19. J Autoimmun 2020; $\operatorname{Aug}(112): 102463$.

58. Jin JM, Bai P, He W et al. Gender Differences in Patients With COVID-19: Focus on Severity and Mortality. Front Public Health. 2020;29(8):152.

59. Li MY, Li L, Zhang Y et al. Expression of the SARS-CoV-2 cell receptor gene ACE2 in a wide variety of human tissues. Infect Dis Poverty. 2020;9(1):45.

60. Kopel J, Perisetti A, Roghani A et al. Racial and Gender-Based Differences in COVID-19. Front Public Health. 2020;8:418.

61. Molloy EJ, O'Neill AJ, Grantham JJ et al. Sex-specific alterations in neutrophil apoptosis: the role of estradiol and progesterone. Blood. 2003;102(7):2653-9.

62. Al-Lami RA, Urban RJ, Volpi E et al. Sex Hormones and Novel Corona Virus Infectious Disease (COVID-19). Mayo Clin Proc. 2020;95(8):1710-1714

63. Sanders JM, Monogue ML, Jodlowski TZ et al. Pharmacologic Treatments for Coronavirus Disease 2019 (COVID-19): A Review. JAMA. 2020;323(18):1824-1836.

64. Ramírez I, De la Viuda E, Baquedano L et al. Managing thromboembolic risk with menopausal hormone therapy and hormonal contraception in the COVID-19 pandemic: Recommendations from the Spanish Menopause Society, Sociedad Española de Ginecología y Obstetricia and Sociedad Española de Trombosis y Hemostasia. Maturitas. 2020;Jul(137):57-62.

65. Gennadi, G. Vitamin D and Quercetin manifest properties of candidate medicinal agents for mitigation of the severity of pandemic COVID-19 defined by genomics-guided tracing of SARS-CoV-2 targets in human cells. Biomedicines.2020;8(5):129.

66. Zhao $\mathrm{Y}$, Ren J, Harlos $\mathrm{K}$ et al. Toremifene interacts with and destabilizes the Ebola virus glycoprotein. Nature. 2016;535(7610):169-172

67. Corrales JJ, Almeida M, Burgo R et al. Androgen-replacement therapy depresses the ex vivo production of inflammatory cytokines by circulating antigen-presenting cells in aging type- 2 diabetic men and partial androgen deficiency. Journal of Endocrinology. 2006;189(3), 595-604

68. Salciccia S, Del Giudice F, Eisenberg ML et al. Testosterone target therapy: focus on immune response, controversies and clinical implications in patients with COVID-19 infection. Ther Adv Endocrinol Metab. 2021;12:20420188211010105.

69. Montopoli M, Zumerle S, Vettor R et al. Androgen-deprivation therapies for prostate cancer and risk of infection by SARSCoV-2: a population-based study $(\mathrm{N}=4532)$. Ann Oncol. 2020:1040-1045

70. Salciccia S, Del Giudice F, Gentile V et al. Interplay between male testosterone levels and the risk for subsequent invasive respiratory assistance among COVID-19 patients at hospital admission. Endocrine. 2020;70(2):206-210.

71. Haitao T, Vermunt JV, Abeykoon J et al. COVID-19 and Sex Differences: Mechanisms and Biomarkers. Mayo Clin Proc. 2020;95(10):2189-2203. 